\section{1. 体市の教師稓について}

\section{傾天堂大学 浪 越 信 夫}

私は「体育の教師観について」考察を加えたいと考え たのは次の如き理由による，1）教員䖯成制度に疑問 を感じている，というのは，教員採用する側から教員の Type は「その分野での expert たれ」「学校体育での 教育者たれ」そのための资を高めるのが大学教育即ち 体育学部や体育科でないたろらか，体育教員採用試験に 特に目立つのは他教科に比交して，常識問題に欠けてい る. 体育教師の昔からの傾向としては，威势よく，之 か，職員会議では末席にいる，ここれは教師の䫓にるよ るが，常に軽茂的な目でみられがちであつたといえる。 体育教師は知的に優秀であれば，常識や技術に欠けて いたりする場合が多い．他教科の教師は目立たないが体 育科の教師は日立つという体育教師の持つ特異的存在に ほかならない，そこで，私は今日の日本の教育体制や社 会体制との関連において，救員養成制度の在り方と，学 科課程の内容や方法の検討，その中で体育教師を位置つ けしよらと考えた。 中村敏雄氏は体育教師像, 武道の現 代化 (体育原理第 2 号) p. 36 の中で「私 ゙すが仲間と して喜んで迎え入れることの出来る体育教師の卵が現在 の教員盖成大学の中で義成されているだろらか，どうで あろらか」といらのであるおおそらく，現場教師の悩み や研究にどれだけの大学教師が耳を傾けてくれるだろう
か.この言葉の咅には日本の体育やスポーツが進歩しな い.いや進歩をはばんでいる要因であるとの御指摘だと 考える.しかし，体育の教師観を論じうとする場合現 時点に㧍ける教師のすへてての教師観でなければならない し，日本の教育，文化をどう発展させるかといらかかわ り合に於て，考えるべき事柄である，そうでなければ体 育の教師観の論藏でしかあり得ない，体育教師に関する 問題はいまさら取り上げるべき問題ですないが，体育教 負養成大学に勤めている教師自身の反省を意味寸るるの である。

柇史的には，戦前の日本に於ける教育体制について， その仕組を日本の资本主義社会の構造を考慮に括いて考 えればより具体的に明らかになる.つまり，1872 年 (明 治 5 年）の構想に始まつた日本の教育体制は明治以降， 大正デモクラシーの波にのつた自由教育も，新教育運動 も国民の生活から切り離された。つまり，日本の教師は このよらな意味において，近代的外形にもかかわらず， その内実は教師として，専門化された仕事を持たない寺 子屋の師匠であつた。それは一面自主性を持たない国家 権力の最末端機構であつたといえる，つまり，明治中期 に確立されたブロイセン，ドイッ帝国型の体制は昭和20 年の敗戦をみるまで本質的に変革することなくつつけら れたといえる。しかし，戦前の文部省支配の体制はくず されたが，いまな招地域単位にはまだ教師の発言の機会 が制限されている。

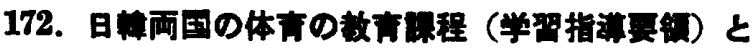 その实施状況に阙する研究}

東京教育大学院○金 貝淑，江层 容

現在の教科体育の学習内容は，日韓両国之も，学習指 运要領により Control されているが現場での実施状況 はどらなつているかを，指独要領に，そつて実状をみよ らとした，その場合，種々の問題点，例えば，地域差な どが考えられるが，今回は一応中学校の年閒計画にみら れる，種目別，時間数についてのみ検討した．調查項 日は，(1)学校の基本条件，(2)教員の構成，(3教員の特

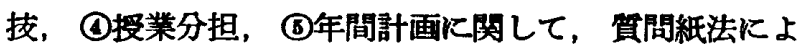
ク，日本では 329 校，暲国任 69 校，その5ち日本 90 校, 韓国では 41 校の中学校を，今回の研究対象とし， 年間計画に見られる．各種目，徒手，器械，陸上，格 技，球拔，水泳，ダンス，知識等の年間時数を，指咅要 領の基淮と比較し，学校の基本年件により，どう変つて いるかを，即ち，優良型 $\mathrm{A}$ ，標準型 $\mathrm{B}$ ，不調和型 C，基 淮以下 $D$ ，爸等型 $\mathrm{E} の \mathrm{ABCDE}$ の 5 段陼において，明 白にしようとした，その結果，俊良型，日本 $7.8 \%$ ，韓
国 $7.3 \%$ ，標潐型，日本 $23.3 \%$ ，韓国 $46.3 \%$ ，不調和 型日本 $38.9 \%$ ，韓国 $14.7 \%$ ，基潐以下，日本 $18.9 \%$ ， 韓国 $24.4 \%$ ，少等型，日本 $11.1 \%$ ，暲国 $7.3 \%$ である. 国の行政から見た場合，8割は基準以上に，確得されな ければならないことからすると，現状では，日本に於い ては $1 / 3$ ，韓国 2/3 の学校でしか基準に 達していないと いら結果になり，日本に比へて，暲国の方がよく実施さ れていると，一応言えたが，雨国ともに，まだまだ問題 点があるように思われる。 しかし韓国では，男女共学で ない故，男女の比較が出来ない点と，種目別に批いて 訓練（教練）を除くと，問題点があると思われる．さら に，基準以下をみると，全体的に，基隼以下のるの，日 本では $11.1 \%$ ，韓国 7.3\% るあるといら結果がでて残 念ながら、はとんど，実施されていない学校もかなりあ るといらことがわかる.なお，どのような条件の学校に 执いて，上く実施されているのか，又どのような学校に おいて実施されていないのか，については，今後の研究 課題としたいと考えている， 